\title{
Members Represent ACRL at Frankfurt Book Fair Highlights of the world's largest trade show
}

A delegation of ACRL members recently represented the association at the Frankfurt Book Fair (October 6-10, 2004). Several of the attendees-James Burgett (University of Kentucky), Julia Gelfand (University of California, Irvine), William Miller (Florida Atlantic University), and Liza Vick (University of California, Irvine)—were awarded partial support from a grant by Amerika Haus to represent the division and interests of North American academic libraries and to articulate to the world's publishing community the nature of our operations.

The Western European Studies Section (WESS) annually makes a call for participation at this conference, and this year broadened the call to include librarians whose duties do not necessarily center on collection development. With the oversight and coordination of WESS colleagues Gordon Anderson (University of Minnesota), Helene Baumann (Duke and incoming WESS Chair), and Beau David Case (University of Michigan), this group set up, staffed, and dismantled the booth and represented the association throughout the fair at a variety of receptions and venues. Several other American and ACRL colleagues who are longtime fair attendees also helped out at the booth from time to time.

\section{The world's largest trade show}

The Frankfurt Book Fair, known as the "Buch Messe," is held at the Frankfurt Messe or Convention Center and occupies 42 football fields worth of exhibition space in a complex of 10 buildings with its own train station stop. The Frankfurt Book Fair is the world's largest trade show for the publishing industry and features massive book and other exhibits. In 2004 there were 336,253 exhibited titles, of which 74,147 were new. There were 6,638 exhibitors from 102 countries with 64 national stands; $41 \%$ of the exhibitors were from Germany and 59\% from abroad. There were also more than 2,000 scheduled seminars, readings, forums, and other events.

In the various buildings, booths are organized by countries, regions, and subjects. As might be expected, the majority of the exhibitors are German, representing an enormously vibrant German publishing industry that keeps prices high for print volumes with government approval. Other major countries represented, in order of size of their representation, were: the U.K., the U.S., Italy, the Netherlands, Switzerland, France, Spain, Austria, and Russia. The major classifications of books and exhibits were: international publishers, fiction, STM and humanities, children's books, tourism, religion, comics, forum management/publishing solutions, and art books/illustration.

William Miller is director of libraries at Florida Atlantic University, e-mail: miller@fau.edu; James Burgett is research and education librarian at the University of Kentucky's Medical Center Library, e-mail: jeburg01@email.uky.edu; and Julia Gelfand is applied sciences and engineering librarian, e-mail: jgelfand@uci. edu, and Liza Vick is research librarian, e-mail: Ivick@uci. edu, at University of California-Irvine.

(C) 2005 William Miller, James Burgett, Julia Gelfand, and Liza Vick 
Each year, the fair honors a different country or culture. This year's honored guest was the Arab World, and 22 Arab League countries responded with booths, some elaborate and extensive, showcasing their publications and culture.

For the fair as a whole, even though nonbook materials and automation were represented, the predominant feature was the traditional print book. The 2004 Fair Catalogue (which is sold, not given away) is more than 2 inches thick with over 1,100 pages, 8,000 entries, and an index of another 350 pages. There is an accompanying "Who's Who" with more than 15,500 names and contacts. The Web site at www.book-fair.com also contains an updated rights catalogue with more than 18,500 titles from 61 countries.

\section{Something for everyone}

For those in the industry, the real purpose of Frankfurt is rights management. The focus of activity for the publishers and agents is deal making, with rights management or the negotiation of rights to publish, translate, distribute, and sell. There are two parts to the rights management program: the "main right," which describes the original edition and language of the book; and then "subsidiary rights," which cover paperbacks, special editions, translations, book clubs, performance, and merchandising. Beyond the rights and other business deals, the trade attendees are there to launch new publications and products, observe the competition, take part in seminars and workshops, and become more aware of the worldwide book market.

For those who are Germanists, the Frankfurt Book Fair offers an unparalleled opportunity to survey the German-language publishing industry in one convenient location, as well as the opportunity to expand one's working knowledge of German-speaking culture and society. The fair also provides the context for an extensive range of literary activities, with fair-related events taking place in the city of Frankfurt and throughout the region. In Frankfurt, for instance, the
Römerplatz, the old city center, is the venue for a series of readings and performances. With the slogan "Leseland Hesse," the entire state of Hesse, where Frankfurt is located, is declared a "reading state." For a Germanist, there can be no better basis on which to make collection development decisions than personal knowledge of the discipline and its practitioners. The fair and associated activities increase one's appreciation of both the content and the context of German-language literature.

There were more than 12,000 journalists covering the event from 81 countries. In the final two days, the general public is allowed in for a nominal fee, and the exhibits are mobbed with young and old. In 2003, the number of visitors was 288,887, 70\% from Germany and 30\% from abroad, with 185,465 identified as trade visitors. The preregistration numbers for 2004 suggest that this year's attendance was slightly higher.

\section{ACRL at the fair}

The most frequently asked questions at the ACRL booth involved how to go about marketing materials to our libraries and how to obtain mailing lists of library addresses. The general public was more interested in overall information about North American libraries. There was considerable confusion about what ACRL is and why we were there. Some attendees wanted to market their products through us, and others were disappointed to learn that they could not obtain borrowing privileges at all of our libraries simply by joining our association!

Sample ACRL publications and promotional literature proved useful for a variety of purposes, including as illustrations of how to advertise. After the fair, we donated the remainder of these publications to the Humboldt University library school, whose booth was next to ours.

The ACRL booth was located on the STM floor, across from the International Library Center. This proved fortuitous since there was an exhibit of professional literature assembled by the German Library Associa- 
tion and prospective librarians often visited there.

A variety of social events complemented the booth duty for ACRL's attendees. Both ALA and the U.S. Consulate had booths, and the latter invited our group to its reception. Other activities included a tour of the Stadt und Universitatsbibliotek Frankfurt, a joint-use library that serves as both the city's and the university's library, and features the artifacts and library of the philosopher Schoepenhauer, as well as an extensive collection of Yiddish materials now being digitized for international access. ${ }^{1}$ The week passed all too quickly but a few of us were able to sneak out in visits to the Goethe Haus and Museum and other cultural spots in Frankfurt. The exhibit organizers graciously coordinated several cultural events for the delegates to attend, including a night at the
Frankfurt opera to see a rather bloody rendition of Richard Strauss' Elektra. Knut Dorn of Harrassowitz hosted a wonderful dinner near the corporate office in Wiesbaden, and Proquest Chadwyck-Healey hosted a dinner in Frankfurt.

\section{Frankfurt in 2005}

The 2005 Frankfurt Book Fair will be held October 19-23, and ACRL members with bibliographic responsibilities for collection development may want to consider this opportunity for professional development. The invited honoree in 2005 will be Korea, whose publications will therefore be featured.

\section{Notes}

1. See www.literatur-des-judentums.de and www.stub.jiddisch.uni-frankfurt.de. n

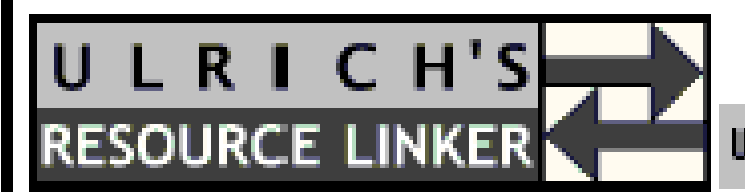

At

An

Link Resolver

Solves Your

Access Needs

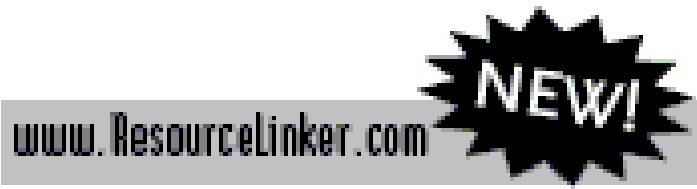

We can have your libray up and running with...

A complimentary, library-specific A-to-z list

- A customized libray branded interface

- An easy-to-use journal and artide search engine

- Intuithe drill-down subject browsing

- Ongoing reliable content updating

- Usage repoting on titles being accessed through ulrichs Resource Linker

Make all of your resources morevisible to users..

Direct users to the full text you've paid for!
Offer patrons Intultive, easy-to-use access to all the resources you want to provide.
To Leam More, contad: orderinfo@bowkercom 